Проф. др Миодраг Вукчевић

Универзитет у Београду

Филолошки факултет $\quad$ 316:821.163.41.09 Андрић И.

mvukcevic@fil.bg.ac.rs https://doi.org/10.18485/ai_andric.2018.ch13

\title{
ИРОНИЈА СТЕРЕОТИПА: \\ КАКО ЈЕ ВЕРОВАЮЕ ГРЕГОРА ФЕДУНА НАДВЛАДАЛО ЊЕГОВУ ПРИРОДУ
}

Од обележавања стогодишњице рођења Иве Андрића до данас, често се полемише о његовим ставовима у погледу мултикултуралности бивше Југославије. Инострана струка и међу њима немачка, од тада се често позива на Андрићеве радове настале у дипломатској служби. Циљ рада је да на примеру епизодног лика из романа На Дрини ћуйрија, по имену Грегор Федун, повеже са једне стране Андрићева гледишта о суживоту у мултикултурној заједници и историјске прилике у Европи с друге. Појединац, метафорично симболишући народну припадност, иронијом његове судбине осветљава друштвене односе и открива стереотипне идеје приписане културама.

Кључне речи: Аустроугарска, Босна и Херцеговина, Галиција, иронија, мултиконфесионалност, стереотип.

[П]ротестантска Краљевина Пруска, нуклеус потоње немачке националне државе, ратовала је деценијама са Аустријском Царевином око Шлезије.

Отприлике као што су православни Срби, босански „Муслимани“ и католички Хрвати

око Босне.

Зоран Жилетић,

Промиитьате gруїих, 1997. 


\section{1. Варијантни дискурси \\ у рецепцији Андрићевог стваралаштва}

Разноликост култура која означава Европу дефинисану као заједнички културни простор, кроз историју континента решавана је различитим облицима друштвеног и државног уређења. Потресна међучинка je, несумњиво, распад земље која се налазила на југоисточним ободима континента. Овде, рекло би се као ни у једном другом европском пределу, наилази се на место културног претовара, узорном за праћење значења културног идентитета њених житеља. Сачуван у усменом предању, као такав и његовом подељеношћу на рубном подручју између два царства остао је у аманет његовом најистакнутијем представнику, чије дело ће генерацијама пројектовати лествицу мерења успеха сагледавања и разумевања народног бића настањеног на овом простору. Иву Андрићу је потом припала колико горка толико и симболична улога представљања борбе за исти тај културни идентитет унутар једног народа.

Како је то случај само са великим делима, коинциденција је хтела да историјска збивања на тлу европског простора, чију вишевековну судбину писац у свом опусу осветљава кроз призму мноштва друштвених мотива, кулминирају у тренутку обележавања стогодишњице његовог рођења. Стављајући их у контекст тада актуелних дешавања није нипошто лако одупрети се утиску о привржености иностране струке централним темама Андрићевих дела. Приликом разматрања мултикултуралности у заједници различитих култура одређене међуверским односима, настојања да се прикажу њени основни конфликти нашла су се пред изазовом решавања дивергентних процеса. Неретко је излаз нађен у дипломатском позиву мислиоца и писца 
Иронија стереотипа: како је веровање Грегора Федуна... 223

који је својевремено интригатној културној различитости из које је потекао, понео светску славу. Додуше, ограничено најпре на Босну, Селие Хоксверт читајући Андрићеву дисертацију упућује на освајања Османског царства и њихово успостављање администрације, што је допринело стварању додатног јаза између католичког запада и православног истока, уместо да спајајући их обезбеди културни развој (2002: 214). Али Андрићева размишљања из домена професионалне, дипломатске струке, ништа ређе нису читана ни у контексту нерешених историјских прилика и, избором прилога тематским зборницима посвећених Андрићевом делу, уврштена потом у одговарајући тематски след одабраних романа (Тирген 1992).

Поред интересовања за његово професионално бављење политиком и дипломатијом, Елизабет фон Ердман-Панџић узрок за Андрићево интересовање испољено према суживоту различитих култура налази у искуству које је писац сакупио у његовој каријери као државни службеник (1992: 9). Али Ердман-Панџићева, мотивисана да дипломату Иву Андрића повеже са друштвеним проблемима исказаним у његовом песничком делу, пренебрегава пишчева упозорења о превеликом значају који се приписује аутобиографским елементима у његовом уметничком стваралаштву. За разлику од тога Селиа Хоксверт уважава најпре упутства о контексту од којег се песник ограђује. На питање о његовом завичајном осећају, о родној кући, Андрићев одговор, према Хоксвертовој, исказ је његове пословичне отпорности на дискусије о приватном животу: „Човек мора негде да је рођен“ (2002: 202). Али јој у образлагању аргументата, ипак, не успева успостављање кохерентног тумачења и ограђивање од тумачења настала у општој атмосфери нетрпељивости током де- 
ведесетих година прошлога века. Сасвим супротно је случај. Позивајући се на Андрићева документа из Министарства иностраних послова која се често цитирају (Андрић, Дипломатски списи, Београд, 1992, стр. 13435), Хоксвертова их пак доводи поново у везу са актуелним дневнополитичким дешавањима (2002: 214) и том приликом приписаним стереотипима.

Другачије прилази Герхард Ресел, стварајући јасну поделу између Андрићеве способности филозофске рефлексије и његове тежње да у свом књижевном делу прикаже свест одређену историјом географских предела (1992: 116). Он Андрићеву дисертацију Развој gyховноі животиа у Босни йоg уйииајем ииурске влаgавине из 1924. убраја међу списе из којих произилазе основна начела у схватању историјске стварности. А за разлику од претходних примера, Ресел пишчево сагледавање друштвених односа одређује кроз однос појединца према историјској улози коју препознаје у претходно омеђеној друштвеној целини (124).

На жалост, резултати приступа попут Реселовог су ограничени и нису битније утицали на његово дискурзивно ширење. Штавише, упркос протоку времена индиферентност ставова ненадано јача. Док Вилфрид Потхоф у Андрићевом схватању Његошевог живота препознаје непрестану и непремостиву муку и тежак рад који књижевном делу конгенијалног претходника приписује одговорно прихватање историјског задатка обезбеђења европске државности и просвећивање заједнице (1992: 92), прилози научној дискусији који стижу са иманентних светских институција, као што је то Томислава 3. Лонгиновића у тематском зборнику из 1995. године о Андрићевом делу, ограничавају свој аналитички домет сужавајући вероиспивести на етницитет одн. националност (133). 
Иронија стереотипа: како је веровање Грегора Федуна... 225

2. Тренутак историјске епизоде

У даљем току излагања, пратиће се идеја која на примеру епизодног лика у роману награђеног Нобеловим признањем, по имену Грегор Федун, Руса из источне Галиције који службује у аустроугарским редовима, повезује Андрићева искуства из суживота народа у мултикултурној заједници са његовом упућеношћу у историјске прилике Европе. Стереотипне идеје које се рађају приписивањем културних карактеристика народима, иронијом Грегорове судбине, метафорично симболизовану у његовом лику, осветљавају друштвене односе разврстане према народној припадности.

Епизодисту Грегора Федуна у роман На Дрини ћуйрија Иво Андрић уводи у 13. поглављу. Након одслуженог војног рока, током којег је провео извесно време у Босни и у Херцеговини, стиснут размишљањима о даљој будућности, он се пријављује поново за даље служење војсци Аустроугарске. Срећа му се није осмехнула само кроз материјалну ситуираност, него и околношћу да је за време док трају устаничке побуне у источној Херцеговини, упућен у сигурну и мирну варошицу на Дрини. Током патролирања и страже на мосту заједно са српским сељаком штрајфкора, прочула се вест о припремама озлоглашеног хајдука Јакова Чекрлије за његов прелазак из Херцеговине у Босну. У исто време, у доба раног пролећа, Грегор примећује младу муслиманску девојку, традиционално одевену, према којој осећа привлачност. Али уместо збижавања момка и девојке, чему се надао, испоставља се несрећном Грегору Федуну да су не само његова природа и осећања преварена већ и приврженост како задатку тако и служењу позиву за који се определио. Због понижења које доживљава током разоткривања појединости њему не- 
милог догађаја, отуђен и остављен сам, налази само једну одлуку исправном - одузима себи живот.

Централни догађај 13. поглавља је значајан за разумевање Андрићевог схватања европске историје и њоме одређене судбине словенске културе са више аспеката. Поред основне поделе у структурне елементе као што су хронотоп, улога ликова и језик као такав, могуће је унутар сваког од њих разврстати додатно према функцији коју преузимају. Убрајање језика у структурне елементе у овом случају је резултат околности да је у свом првом издању из 1945. роман објављен на ћириличном писму, исто као и издање из 1962. које је коришћено овом приликом.

Наиме, значај културне функције коју Иво Андрић додељује писму, могуће је уочити када се у радњи појављују тзв. штрафкори. Писац их издваја тек наводницима додатих речју исписаном језиком и писмом порекла. У даљем току назив се појављује транскрибовано, што јасно мења значење. Значењем извиђачких јединица, назив штрајфкор се појављује у немачкој војној историји за време Другог светског рата и означава јединице за потребу подршке такозваних Feldjägerkorps, који су заузимали највише место у заповедном ланцу војне полиције немачког Вермахта. Андрић, тако што ће у даљем току радње наставити са коришћењем немачких позајмљеница за именовање војних чинова и функција, указује у суштини на културне разлике али сада између немачког као германског бића и опште словенског. Притом, стилизована појава ликова попут ритмајстера Крчмара „са невидљиво ситним брчићима, са тамним подочњацима који су око сивих очију стварали правилан круг“ (1962: 206), треба, нема сумње, да остави утисак чувања дистанце. Отпорност правилно уређеног система засигурно неће поколебати „опуште- 
Иронија стереотипа: како је веровање Грегора Федуна... 227

не маљаве руке“ вахтмајстера Драженовића нити „тешка бурма од злата“ која „је блештала“ на једној од њих (ибид). Ипак, „са црном кратком брадом“, познат као „строг човек“ његова оштрина симболизује традицију према којој се појединац подређује заједници и њеним правилима.

Помоћу језика Андрић ствара додатну дистинкцију која је најпре варијантног карактера и односи се на нешто што је заједничког порекла. Разлика између културе и различитих облика кроз које се она артикулише, представља у ствари дистинкцију унутар једне јединствене културе. У том смислу, изражавање културног идентитета помоћу језичких облика добија на значају приликом одређивања појединца према заједници којој припада. Коришћењем варијантног облика наречја за стварање дистинкције и издвојено исто тако наводницима, „тијесно одјело“ које је због регрутације широм Босне и Херцеговине народ приморан да обуче и стави се у службу туђег цара друге вере, пројектујући контраст „штрајфкорима“, изражава пре свега скученост, скученост простора чије се статистичко захватање спотиче о културним границама.

Поделом улога ликовима у 13. поглављу Андрић их уздиже, свакако, у носиоце културних обележја. Од културе одевања преко обичаја конзумирања хране и пића, па чак и забаве, читалаштво се, додуше, с једне стране смешта у атмосферу живе мултикултуралности, али му се исто тако показује, с друге стране, да се њено постојање гради на култури чији се опстанак доводи у питање. Свет у којем се налази централни лик епизоде, представљен је још на почетку поглавља. То је свет угледних муслиманских становника касабе, „Турци“ како их Андрић назива. Доласком Грегора Федуна у ту средину успоставља се међутим однос између културе 
ове средине и њега као личност. А његова личност је одређена првенствено послом којим се бави. Припадник је војних формација Аустроугарске и у том својству члан нове власти, „омражене“ власти. Али о његовој личност сазнајемо много више упознајући околности из којих потиче. Рус из Источне Галиције „[т]опио се од милине и надимао од поноса замишљајући лица родитеља, браће и сестара кад приме прве сребрне форинте које ће им он послати од обилне штрајфкорске плате“ (Андрић 1962: 199). Породични живот и начин организације породичних прилика пружа увид како у јунакову социјалну ситуираност тако и у његово схватање привржености социјалним вредностима. Према томе, конструкција бинарног разликовања одн. дихотомија се успоставља дуж осе културног идентитета. Јунак епизоде припада иначе народу који чини мањину у својој земљи. А културна припадност се дефинише на локалу, и тако што је Грегор током стражарења „певушио све малоруске песме које се у његовом крају певају“ (200). Пореклом из највећег словенског народа он преузима улогу антипода култури свог окружења, како у матици тако и у међународној мисији. Мера у којој су његови сународници заступљени у структурама власти које представља, одговара истој оној мери у којој је његова култура укључена у јавни живот у свету којим влада. То даје повода за размишљање о разликовним обележјима значајним за разликовање култура.

Упркос томе што је Грегор унијата, одлука да се сахрани по источном обреду мотивисана је идејом достојанства живота садржаног у реторичком питању пароха попа Николе „ко би смио опет узети на душу да га покопа к’о никакву вјеру, неђе иза плота и без свештеника?" (215). Без обзира на обичај унијатске цркве, по којем се служи по источном обреду, овим се наговеш- 
Иронија стереотипа: како је веровање Грегора Федуна... 229

тавају будући културни токови, када „послије, ако икад наиђе неки поп његовог закона, он нека дода и поправи, ако нађе да нешто није било како треба“" (ибид). Достојанство постојања не нестаје смрћу, из чега се може донети закључак о толеранцији према животу.

Време радње је смештено, како се каже, када је „наступила четврта година окупације“ (195) одн. од Берлинског конгреса 1878. год. и две године након мучног пописа становништва из 1879. Те 1881. год. Грегор се вратио, сазнајемо, поново у пределе којих се радо сећао као „босанске планине и варошице у којима је проживео и тешких и веселих дана, а за које су га сада везивала сећања у којима су они тешки дани лепше и живље сјали од веселих“ (199). Припадник сада војних формација Аустроугарске управе, штрајфкора, предходно је боравио у Босни током „отслужења [војног] рока“. Тада је учествовао „у бојевима код Маглаја и на Гласинцу“ (ибид). Иначе, не наводе се године Грегоровог ваљда редовног служења војног рока, већ само податак да је после учешћа у бојевима „провео годину и по у разним гарнизонима источне Босне“ (ибид) и да је после тога боравио извесно време у Пешти када је „објављен позив за добровољни упис у штрајфкоре“ (ибид). Време радње се додатно одређује наводима о пристизању војних одреда Аустроугарске, о организовању „Streifkorps [...] чим је устанак у Херцеговини почео да узима озбиљне размере“ (198). Узимајући у обзир да је дизање устанка у Херцеговини почело деценијама раније, и док је Босна и Херцеговина тек после Берлинског конгреса створена као јединствена управна јединица, а Грегор Федун учествовао у бојевима у оба њена дела, јасна је једино намера песника да читаоцу компресијом временског следа пренесе стање несигурности тог времена. 
Из описа временског оквира радње није дата могућност смештања епизоде у историјски оквир, но у односе који су изван времена и простора. Пошто је тема културе, и мултикултуралности, тј. човеково бављење односима у предметном и духовном свету који га окружују, такође, безвремена и просторно неограничена, то су одреднице културног организовања, цивилизацијских тековина, полазне тачке за успостављање могућих релација. Њихово подударање или контрастивно разликовање, штавише, нуди изгледе за боље разумевање комплексних односа садржаних у роману. Устаљено мишљење о трима хроникама, вишеградске, травничке и сарајевске, помоћу којих је Андрић описао историју босанског друштва, треба због њихове различите временске концепције, ипак, сматрати релативним. Нису само различити временски периоди ти који стварају јасну дистинкцију, него и период обухваћен у сваком делу понаособ. Хронотопска одредница посматрана у контексту Андрићевог стваралачког опуса доводи, уосталом, у питање или пак релативизује хронику као поступак у Андрићевом стваралаштву. Исто се потврдило претходно још у случају назива војних јединица.

\section{3. Иронија стереотипа}

Епизода у којој је требало да дође до зближавања момка и девојке, уместо испуњеним животом завршава његовим крајем. Описани односи из перспективе момка, Грегора Федуна, узрочно-последично повезују с једне стране подривање јунаковог веровања у достојанство људског постојања и са друге стране његову приврженост професионалном задатку, војничком позиву, која се доводи у питање. Конфликт који је Андрић, на 
Иронија стереотипа: како је веровање Грегора Федуна... 231

примеру епизодног јунака, пресликавањем културних односа пореклом из Аустроугарског царства пројектовао на босанско друштво унутар Османског царства, када се пренесе на перцепцију сложених односа на Западном Балкану данас, али и изван самог подручја, у средиште проблематике којом се Андрић бави, смешта питање контекста у којем је сама њена природа сагледана и самим тим њеног разумевања. Критичка биографија Иве Андрића из пера Ваните Синг Мукерји (1990) настала у предвечерје избијања оружане потраге за решењем конфликата насталих у југословенском народу, показује, међутим, да је претходно поменути културни контекст био, нема сумње, познат. Описом Андрићеве свести као „балканске“ сконцентрисане на граничном подручју измеђи Истока и Запада, Мукеријева Андрићево дело чита као дело писца који је у двадесетом веку, прекорачујући границе националног идентитета, дотакао само биће људског постојања уопште (р. х).

Према томе, оправдано је донети закључак да Андрић културу домицилног становништва тумачи исто тако у контексту културних утицаја којима је оно изложено. Остваривањем друштвеног живота у окружењу обележеног различитим културним облицима, рађа се, неминовно, како тежња за афирмацијом оних културних садржаја према којима се, као носиоцима идентификационих обележја, испољава припадање, али тако и отпор према садржајима културе друге врсте. Сведено на простор централног региона Западног Балкана хронотопска одредница стиче епитет поменутог скученог простора одевеног у $\bar{u}$ иесно оgјело. Метафором исказан отпор једног дела становништва на тај начин се доводи у везу са извором културе манифестоване у шитрајфкорима, са вредностима које као њихови чувари представљају, са редом и миром. 
Паралела, на коју нам Андрић примером овако устројених односа указује, говори заправо о култури која у систему власти тежи остваривању својих етичких вредности на начин да себи оствари идентитетска обележја, помоћу којих се културно препознаје. Према Иштвану Лекешу, књижевну грађу за његове доживљаје Андрићу представља босанска реалност у периоду од 1878. и 1914. присутна у књижевности народа бивше монархије (1992: 79). Иво Андрић се очигледно позива на „доживљај монархије“ (80), њему познат из пољске литературе на тему Галиције која у белетристичким облицима преноси доба монархије (79). Аустроугарска свој однос према Галицији, подељеној на западни и источни део, обема деловима од 1867. до 1918 године крунске земље цислајтанског, аустријског дела Аустроугарске, исказује у ствари учешћем, укључивањем домицилне културе у управне структуре. Пољаци из територијално мањег дела, из Западне Галиције, финансијски подржани, заузимали су високе службеничке позиције, функције министара или чак премијера. Аналогно односима постојећих у Босни и Херцеговини, поред релативних разлика у погледу на одлуке донете на Берлинском конгресу, заједничка управа два царства се разликује још за однос власти успостављеног према вероисповести. Док су „Турци“, муслимански становници касабе у улози антипода Грегору Федуну, представнику хришћанског запада, критичном епизодом се тематизује за разлику од тога њихов однос, понаособ сваке културе за себе, према Србима. Али појава Грегора Федуна, унијате и припадника руског, у својој земљи мањинског народа, заправо је сублимација односа западног хришћанства према својој историји. Лицелерова теза, по којој се европска мултикултуралност дефинише како из односа хеленизма и римског наслеђа 
Иронија стереотипа: како је веровање Грегора Федуна... 233

тако и хришћанства према јудаизму (2003: 50), однос区 не увек изразито хармоничних, у Андрићевом делу они су притом већ сажети. Такође, однос цивилизација из европског античког доба према Јудаизму никада није дефинисан на основу разумевања властите културе као заокружене која се ограђује од културе препознате као стране (ибид). Сублимацијом, дакле, и потом успостављањем релација према муслиманском свету, из њих извире, управо данас, у светлу актуелне мигрантске кризе, потпуни значај Андрићеве поруке.

У симболичној улози Грегора Федуна огледа се према томе однос културе израсле у владарско царство, овде Аустроугарско, према културама које израз свог религијског бића налазе у другачијем облику. Пример положаја унијата унутар западнохришћанске цивилизације преузима, следствено, поредбену функцију за словенску културу уопште. На тај начин се мултикултуралност, да ли редукована или пак уздигнута на раван културних разлика између немачког као германског бића и опште словенског, симболизује у српској судбини. Андрићев свет мултикултуралности лоциран на балканском размеђу култура, препознаје, још својевремено, културу као плод успеха њене институционализације, њеног прилагођавања структурама власти. Описаном распореду снага, двема главним заједницама народа настањених у Европи приступа на овом простору трећи, „турски“ утицај, који у датој констелацији развоју култура доприноси науштрб највеће културне заједнице, тј. словенске културе.

Ако је Иво Андрић већ сам недвосмислено ставио до знања да би требало избегавати повезивање његовог приватног живота и списатељског опуса, онда све до данас још ништа није допрло до јавности што би говорило против успостављања везе између професио- 
налног, дипломатског позива и Андрићевог песничког истраживања, песништва као таквог. Из Андрићеве дисертације следи, наиме, како то Ханц Петар Штофел налази (1992: 163), не једна општа критика муслиманске културе, него разматрање последица њеног преноса на земљу словенског хришћанства. Излаз из аргументације засноване на стереотипним идејама, међутим, Андрић нуди управо осликавањем детаља из суживота на културном тромеђу. Овде се достојанство рађа из толеранције према животу. Тиха иронија је свакако то што писац њу разгољева и то тако што је ставља наспрам организованог обезбеђивања услова за живот, алегорично представљено у штрајфкорима. Из односа према њима произилазе потом два начела која одређују положај човека у животу и његово схватање истог. Остварено с једне стране кроз понизност у држању, Стеван, припадник штрајфкори, сељак из Праче подређивањем поретку преузима улогу која се препознаје у прилагођавању друштвеној стварности, култури успостављеној кроз институционално преношење етичких вредности. С друге стране, колаборационисткиња Јеленка и њен узајамни однос према припадницима народа чија власт чини други део управе, а којима је и претходно одело било тесно због укрштених каишева, налази заједнички именитељ у отпору према омраженој власти.

Данас о међукултурним прожимањима на предметном простору сведочи неологизам такозване 'балканизације' односа, али упућује сада, и то упркос сазнању о карактеру веза у мултикултурној заједници које нам Андрић нуди, неочекивано у супротан правац. Сходно томе се поставља питање мере разумевања исказаног у иностраној секундарној литератури према Андрићевом гледишту. Коначно, оно је од пресудног значаја, ако се узме у обзир културни контекст у који 
Иронија стереотипа: како је веровање Грегора Федуна... 235

Селија Хоксверт смешта Андрићеве одлуке, попут његовог преласка из Загреба у Београд. Исти она описује као одлуку просперитетног младог писца, о одустајању од Загреба, културног центра понајвише европске провинијенције, у корист полуоријенталном балканском запећку Београда (2002: 203).

Ипак, у стручном прилазу на немачком говорном подручју наилази се и на издиференцирану перцепцију конфликтног потенцијала мултикултуралности на Балкану. Као што је потребно обезбедити доследност приликом утврђивања налаза, узимајући притом у обзир горе напоменута тумачења улоге Његоша у Андрићевим есејистичким радовима или чак тумачење рецепције Андрића у Срба за време ратова деведесетих, тако не треба губити из вида симбол ћуприје, мукотрпног изграђивања заједништва у мултикултурним односима. Тако Паул М. Лицелер истиче значај песничке интертекстуалности у Хандкеовом Зимском йуйовану када говори о Андићевом роману у знаку наде (2003: 51). Приврженост тексту у херменеутичком приступу у начелу не дозвољава никаква друга тумачења. Култ мржње, на пример, који се неретко ишчитава из Андрићевих романа у односу на приказ муслиманског света у Босни (Ким 2011: 55), упркос његове пројекције мутатис мутандис према Србима, као последице манифестације нетрпељивости према другим вероисповестима и страним цивилизацијским облицима, помаже заправо трећим културама да уоче ваљда сигуран властити напредак. Али иронијом ове врсте, наиме, иронијом попут градијетног осећања олакшања или пак среће у тренутку непосредног доживљаја смрти друге особе, Андрић, штавише, отвара свој роман. Радисавовим отпором према страном утицају који мења свет какав познаје и туђом влашћу која ломи предводника 
диверзије и кажњава га јавним погубљењем за пример, поприма обележја приношења жртве: „Већ по начину како су се спустили на обалу и прошли ћутке између запослених људи, сви су схватили да је сељак издахнуо. И сви су Срби осетили неко олакшање, како невидљиву победу. [...] Смрт је најтежи залог“ (Андрић 1962: 71).

Могућност препознавања правца усмереног у супротном семру, Паул М. Лицелер види у захтеву за повратак пажње посвећене детаљима у животном окружењу. Судбина пореклом са простора који се поново нашао у нуклеусу историјских збивања, према његовом схватању зависи од „умећа суштинске доколице“ (1998: 120). Поступак остварен према том начелу, који препознаје у Андрићевом приповедању, налази и у Хандкеовим делима. Поклањање пажње поново детаљима из животног окружења, дакле, описима трговине, пијаца, карактеристичних предела природе, улица, подсећа на заједништво за разлику од учесталог оживљавања разарања из прошлости.

У погледу на изузетно сложене односе у мултикултурној средини, било који резултат добијен из неисторијског приступа, треба узети у обзир према томе само у одговарајућој критичкој мери. Наиме, ако се мултикултурној Аустроугарској призна дипломатски успех из 1912. онда је амбивалентност испољена према Андрићевој дипломатској каријери (Ердман-Панџић 1992: 16) заправо плод неразумевања културних идентитета настањених на простору у којем се поменута европска сила својевремено бавила више контролисањем, управљањем и ширењем утицаја него организовањем културног живота. Отуда није тешко испратити неспоразуме који настају када се занемари мултиконфесионални карактер мултикултуралности или када се верско опредељење и култура, штавише, поистовете. Слика 
потпуне збуњености се ствара поготово изједначавањем вероисповести, наречја и писма (Ердман-Панџић 1992: 10). Данас, иронија се огледа управо у обузетости широке стручне јавности темама миграције и тероризма, док усамљена гледишта позивањем на стављање ових појава ad acta, решење налазе у сећању на заједништво. Свако инсистирање на оквир рецепције који језик и писмо у Андрићевој употреби доводи у везу са устаљеним оживљавањем вековима мукотрпно превазилажених конфронтација, говори о истој мери разумевања појаве зайаgнобалканске мултикултуралности као што је то рецепција хајдучине као клице духа тероризма у италијанској и енглеској литератури.

\section{Извори и литература}

Андрић, Иво. Развој gуховной животй у Босни йоg уйицајем йурске влаgавине. Београд: Просвета, 1995. Штампано.

Андрић, Иво. На Дрини ћуйрија. Београд: Просвета, 1962. Штампано

Erdmann-Pandžić, Elizabet fon. „Das Referat von Ivo Andric vom 30.1. 1939 und die Nordalbanienfrage im serbischen Nationalismus." Ivo Andrić 1892-1992: Beiträge des Zentenarsymposions an der Otto-Friedrich-Universität Bamberg im Oktober 1992. $B d$. 25, Vorträge und Abhandlungen zur Slavistik. Peter Thiergen (Hrsg.). München: Verlag Otto Sagner, 1995. 9-22. Štampano.

Hawkesworth, Celia. „Ivo Andrić as Red Rag and Political Football." The Slavonic and East European Review. Vol. 80, No. 2 (Apr., 2002): 201-216. Веб. JSTOR, JSTOR, www.jstor.org/stable $/ 4213436$

Lőkös, István. „Die Doppelmonarchie als Thema im Werk von Ivo Andrić." Ivo Andrić 1892-1992: Beiträge des Zentenarsymposions an der Otto-Friedrich-Universität Bamberg im Oktober 1992. Bd. 25, Vorträge und Abhandlungen zur Slavistik. Peter Thiergen (Hrsg.). München: Verlag Otto Sagner, 1995. 79-89. Štampano. 
Longinović, Tomislav Z. „East Within the West: Bosnian Cultural Identity in the Works of Ivo Andrić." Ivo Andric Revisited: The Bridge Still Stands. Wayne S. Vucinich (Ed.), Berkeley: University of California, 1995. 123-138. Ве6. 01.01. 1995.

Lützeler, Paul Michael. „Multikulturelles, Postkoloniales und Europäisches in der Postmoderne: Zur Internationalität der deutschsprachigen Gegenwartsliteratur." Hirst Turk, Brigitte Schultze und Roberto Simanowski (Hrsg.): Kulturelle Grenzziehungen im Spiegel der Literaturen. Nationalismus, Regionalismus, Fundamentalismus. Göttingen: Wallstein Verlag, 1998. 104-121. Štampano.

Lützeler, Paul Michael. „Paris und Wien oder der kontinentale Grundkonflikt. Zur Konstruktion einer multikulturellen Identität in Europa." Monika Mokre, Gilbert Weiss und Rainer Bauböck (Hrsg.) Europas Identitäten. Mythen, Konflikte Konstruktionen. Frankfurt/ New York: Campus Verlag, 2003. 3654. Štampano.

Mukerji, Vanita Singh. Ivo Andrić, A Critical Biography. North Carolina and London: McFarland \& Company, Inc. Publishers, Jefferson, 1990. Štampano.

Potthoff, Wilfried. "Andrić und Njegoš." Ivo Andrić 1892-1992: Beiträge des Zentenarsymposions an der Otto-Friedrich-Universität Bamberg im Oktober 1992. Bd. 25, Vorträge und Abhandlungen zur Slavistik. Peter Thiergen (Hrsg.). München: Verlag Otto Sagner, 1995. 91-102. Štampano

Ressel, Gerhard. „Individuum und Gesellschaft im Romanwerk von Ivo Andric." Ivo Andrić 1892-1992: Beiträge des Zentenarsymposions an der Otto-Friedrich-Universität Bamberg im Oktober 1992. Bd. 25, Vorträge und Abhandlungen zur Slavistik. Peter Thiergen (Hrsg.). München: Verlag Otto Sagner, 1995. 115-130. Štampano.

Sang Hun, Kim. „Andrić as an Object of Hate: Reception of Ivo Andrićs Works in the Post-Yugoslav Context.“ Slavistična revija, 59/1 (2011): 49-63. Štampano.

Stoffel, Hans-Peter. Ivo Andrić: „A Yugoslav Career“. New Zealand Slavonic Journal Australia and New Zealand Slavists' Association, (1992): 159-170. Веб. JSTOR, JSTOR, www.jstor.org/ stable/40921433 
Иронија стереотипа: како је веровање Грегора Федуна... 239

Thiergen, Peter (Hrsg.). Vorträge und Abhandlungen zur Slavistik Bd. 25, Ivo Andrić 1892-1992. Beiträge des Zentenarsymposions an der Otto-Friedrich-Universität Bamberg, Verlag Otto Sagner, München: 1995.

\title{
Miodrag Vukčević
}

\author{
THE IRONY OF STEREOTYPES: \\ HOW GREGOR FEDUN'S NATURE \\ WAS OVERCOME BY HIS CONFIDENCE.
}

\begin{abstract}
Summary
Dealing with conditions in a multicultural society characterized by multiconfessionalism faces the challenge of resolving divergent processes when describing their fundamental conflicts. One of the strategies is often the diplomatic vocation of the thinker and poet Ivo Andrić, who helped bring the intriguing diversity of his culture of origin to world fame. Stereotypical ideas that are formed attributing cultural features illuminate the social relations in the ironic fate of Gregor Fedun as a symbolic metaphor, which are paradigmatically summarized in ethnicity. Today, the neologism of the so-called "balkanization" of conditions for multicultural interdependence, unexpectedly point in the opposite direction despite the knowledge offered by Andrić. If one wishes to recognize the diplomatic success of multicultural Austria-Hungary in 1912, then the ambivalence that is shown towards Andrićs diplomatic activity is actually a result of misunderstood cultural identities in the Western Balkans. A picture of complete confusion is created in particular with the equating of creed, dialect and scripture.
\end{abstract}

